\title{
PETER SLOTERDIJK. DE LA VIDA EN EJERCICIO AL OPTIMISMO SOCIAL ILUSTRADO
}

\author{
Antonio Ríos Rojas \\ Universidad de Salamanca
}

http://dx.doi.org/10.5209/rev_NOMA.2013.v40.n4.48337

\begin{abstract}
Resumen: Presentamos el pensamiento de Sloterdijk apoyándonos en el "concepto-muleta" de "optimismo". Tratamos de estudiar los fundamentos desde los cuales, para Sloterdijk, puede hacerse nuestro planeta más pacíficamente habitable y nos centramos especialmente en Has de cambiar tu vida e Ira y tiempo, mostrando también las dificultades -a veces contradiccionespara mantener dicho optimismo de corte ilustrado. He aquí, en todo caso, el juego del discurso filosófico de Sloterdijk que, antes que nada, huye del estricto arte argumentativo y, por lo tanto, no debe temer en exceso a las contradicciones. Nosotros nos apoyamos, sin embargo, en estos abstractos conceptos: "argumento", "contradicción", para presentar propedéuticamente el que será el primero de una serie de trabajos sobre el filósofo alemán.

Palabras clave: optimismo, metanoia, thimos, inmunología, verticalidad.
\end{abstract}

Peter Sloterdijk. From life as an exercise/a practice to an enlightened social optimism.

Abstract: We present the concept of Sloterdijk, based on the "term of crutches" of "optimism". We try to explore the basis upon which, as for Sloterdijk, a more peacefully inhabitable world can evolve. The study is particularly centered on his books "You Must Change Your Life" and "Anger and Time", depicting the difficulties - sometimes contradictions - of maintaining this enlightened optimism. In any case, it is demonstrated that Sloterdijk is playing a game in his philosophical discourse that escapes the strict argumentative art, evading conflicts in regard of content. However, we base ourselves on following abstract concepts: "argument" and "contradiction" to propaedeutically present the first in a series of articles about the German philosopher.

Keywords: optimism, metanoia, thimos, immunology, verticality

\section{1.- A MODO DE PRESENTACIÓN. UN ESCENARIO OPERÍSTICO U ORQUESTAL. SLOTERDIJK, UN FILÓSOFO ILUSTRADO.}

El incomparable crítico musical Arturo Reverter, en su programa "Ars canendi" de RNE, se lamenta con frecuencia de la extinción del registro de "bajo profundo" en el arte del canto y en especial de la ópera. Me pregunto si al oír la voz hablada de Peter Sloterdijk resonar como un oráculo procedente de profundidades telúricas o cavernosas, parecida a la voz de Dios en "Los diez mandamientos", este excelente crítico musical no la oiría con cierta melancolía, viendo tras ella la posibilidad de un excelente Don Basilio, de un riguroso Felipe II, o de un intachable ético universal Sarastro ${ }^{\underline{1}}$. 
Espero mostrar en este artículo, yendo más allá de esta mera exageración introductoria, que las supuestas añoranzas de Arturo Reverter no serían del todo baldías, si bien con importantes matices.

Alguna vez se ha dicho -creo que por parte de Rudolph Carnap- que detrás de todo filósofo hay un músico frustrado. Nietzsche, que es el pensador más encomiado por Sloterdijk, y casi desde el cual arranca su pensamiento, lo era. Pero la frustración respecto a la música bendice la dedicación de estos "frustrados" a la escritura, que alcanza en ellos una elevación y una profundidad insólitas.

En este sentido, son los libros de Sloterdijk extremadamente musicales y se ve en ellos el canto de un bajo profundo o de un contrabajo, en el sentido que el primero tiene un papel más de fondo en la escena, en el sentido que los contrabajos se sitúan al final de la orquesta. Peter Sloterdijk se sitúa en escena como observador distante de la realidad, penetrando, sin embargo, más que ningún tenor, más que ningún primer violín, en "la esencia de la realidad". Así como esencia primera de lo real comprende Schopenhauer al contrabajo en la música o a la arquitectura en las artes plásticas.

El filósofo crítico -si es que hay algún filósofo serio que no lo sea- asume por necesidad este papel de bajo, y deja el papel de tenores, sopranos, y primeros violines, quizás para el deportista o para el político. Sin embargo aquí la voz de bajo no es la de un mero acompañante de la melodía clara, sino que se convierte en su contraposición; por ello pasa el filósofo a escena a veces; en primer lugar, por oponerse a las corrientes y a las melodías. Sabedor de que pasa a escena con su tesitura de bajo o tocando el contrabajo, es como Sloterdijk aparta las melodías cerradas como locura de la razón. La mayor locura de la razón es la dialéctica, pues conlleva en sí el deseo nocivo de victoria intelectual. La crítica general de la Escuela de Frankfurt, la dialéctica negativa de Adorno, no abandonan este deseo de victoria de la razón, es por ello por lo que la filosofía se enmohece en su sistema y se aparta de lo concreto, reniega de lo cercano. La victoria cierra y enmohece, y por ello Sloterdijk es un crítico más allá de lo crítico, viendo que la crítica, especialmente la llevada a cabo por la Escuela de Frankfurt, se ha acabado convirtiendo en un sistema a medio camino entre la cárcel y el caos. Y esto, porque la pretensión abarcadora de la razón jamás podrá afrontar el universo en su complejidad, comenzando los críticos a sentirse en su crítica y en su total desconfianza en una cárcel en la que todo está desordenado, en una prisión caótica que acaba distanciando todo de todo. El caos distancia, más que juntar el caos amontona a las cosas, y por ello Sloterdijk ve a la objetividad crítica y la dialéctica como el método que acaba pagándose con el alejamiento de las cosas. Cuando todo se hace objetivamente problemático, ya da todo igual, y lo cercano aparece como lejano.

El contrabajo que comienza situado al final de la escena, se va acercando a ella poco a poco y, en su disonancia, se muestra como más cercano, más que los primeros violines que cierran la melodía al definirla. Acercándose así a la realidad de la escena aparece Sloterdijk con la risa de Diógenes y la animosidad -Heiterkeit- de Nietzsche ${ }^{2}$. Schopenhauer afirmaba que el contrabajo era el más "físico" de los instrumentos de cuerda, era la manifestación más viva de lo corporal, por ello nos valemos de esta imagen del 
contrabajo para abrir las puertas a Sloterdijk-Diógenes que viene a reivindicar al cuerpo como lo que siente al mundo, y restituye la cercanía.

Peter Sloterdijk convierte el papel de bajo profundo en un verdadero virtuosismo. Contrariamente a Nietzsche -al menos en una buena fase del pensamiento de este último-, no cae en la posición postromántica de la crítica devastadora-depuradora, desde la cual los cambios sólo son posibles si son absolutamente verticales, por el contrario Sloterdijk está más cerca del cinismo de Diógenes y de la "Heiterkeit" -alegría despreocupada- de Nietzsche, y pese a todo, también está Sloterdijk más cerca de la Ilustración, en el sentido que hay en ésta un optimismo social que se sitúa por encima, o mejor dicho, a continuación de la crítica -matizo para mostrar la no verticalidad depuradora-. Sloterdijk revitaliza y reanima la llustración ${ }^{-}$, que en su desarrollo ulterior derivó en un oscurecimiento cerrado cientifista, o en la ya mencionada oscuridad y cerradura de la victoria crítico-dialéctica. Muchos años después de su irrupción a escena en 1983 con La crítica de la razón cínica, en Has de cambiar tu vida el filósofo llustrado ha dejado algo de lado a Diógenes y a la "Heiterkeit" nietzscheana, y exige el cambio de rumbo en la filosofía, reclamando de ella el giro del filósofo, de crítico ha de convertirse en el afirmador de la civilización, apoyando sus razones civilizadoras y altruistas en una teoría que ya vino llamando desde hace años "inmunología general"․․ Quizás la destrucción que vimos el 11 de septiembre de 2001, y la crisis económica -entre otras cosashan motivado a Sloterdijk a dejar de meterse en toneles. Hay en el pensador de Karlsruhe, en efecto, un mayor anclaje y parentesco con la realidad y quiere instaurar en ella motivos de optimismo social. Él mismo se dejará ahora inspirar mucho más por Heidegger, por la condición humana como ser-en-el mundo de Heidegger, valorando, pero huyendo de los escapismos "metanoéticos" tanto individuales como grupales; escapismos que ya censurara desde su primera obra Crítica de la razón cínica. Esta frase de Goethe la acoge Sloterdijk como una guía de la modernidad, y un leit motiv último de su postura optimista: Profetas por la derecha, profetas por la izquierda, en medio la criatura del mundo ${ }^{\underline{5}}$. Sin embargo y pese a ello, Sloterdijk es el crítico social más mordiente que quepa imaginarse. Cómo esta crítica feroz intenta -desde nuestro punto de vista sin lograrlo- no caer en el pesimismo es lo que, entre cosas tratamos de dilucidar aquí, especialmente en nuestro último capítulo.

Pero no creamos que su giro hacia lo civilizatorio -que nunca fue negado en ninguna de sus obras- ha hecho desaparecer a Diógenes y a Nietzsche de su corporalidad. Su estilo ha sabido armonizar un lenguaje altamente técnicocontemporáneo y a la vez altamente poético ${ }^{\underline{6}}$, todo ello bañado de un fuerte sarcasmo, como si su obra fuera el resultado musical de mezclar Alban Berg y Beethoven, siempre bajo la estela de Rossini. Por ello a veces aniquilará con su crítica y su risa, por ejemplo, al comunismo mientras otras veces vemos un velado encomio de su espíritu, a veces arremete sin piedad contra Pablo, mientras no deja de haber en otros momentos una alabanza radical hacia su figura. Y más importante aún, destrozará la modernidad, y habrá un esencial y más que importante encomio de su espíritu, pues es Sloterdijk un filósofo que se inserta de lleno en la modernidad. Este soberano filósofo, o ensayista o crítico, o simplemente escritor, muestra sin embargo, infinidad de contradicciones cuando se arroja en manos de la construcción político-social. La riqueza y la belleza de sus libros al analizar críticamente la filosofía y su 
historia como una antropotécnica y como un desarrollo de sistemas inmunitarios psíquicos, simbólicos -entre ellos la religión- quedan fuera de toda duda, pero en este corto ensayo fijaremos nuestra atención en cómo este inmenso analista no es capaz de nadar con solvencia en el mar de las soluciones -o quizás haya ido demasiado lejos, y más que nadar haya aprendido incluso a bucear-, pues a veces da la sensación de nadar con la alegría y despreocupación del que carece de la técnica para nadar y sólo chapotea mientras cree sentirse Michael Phelps. No ignoramos las palabras de Rudiger Safranski, que al referirse a los críticos de Sloterdijk comenta: ...Sloterdijk ha seguido avanzando... Demasiado, dicen críticos suyos poco audaces, que muestran así no haber comprendido que hay que ir demasiado lejos para llegar a la meta ${ }^{7}$. Este pensamiento, cierto, y que el mismo Sloterdijk acogerá como leit motiv en Has de cambiar tu vida, no nos priva, pese a todo, de mostrar la polémica de su toma de partido prácticopolítico y las posibles contradicciones que alberga.

No concluiremos que será más conveniente para quien no sabe nadar quedarse en tierra firme, sino que sólo advertimos, que la otra opción, meterse en el agua de las soluciones político-sociales -aprender a nadar- implica la conversión en hombre práctico, para lo que Sloterdijk tendría que cantar en una misma representación de ópera los papeles de Don Basilio, de Felipe II y de Sarastro, lo cual se nos antoja imposible. Pero también advertimos lo ya apuntado: quizás Sloterdijk bucee y no nade, y de ser esto así, sus libros no sólo nos muestran al crítico brillante, sino al sabio que es capaz de tocarnos en nuestro más hondo interior y ayudarnos, como los sabios estoicos, a "cambiar nuestra vida". En este sentido nunca uno, por muchos chapoteos que descubra en las soluciones políticas de Sloterdijk, dejará de ver al filósofo de Karlsruhe como un maestro de vida. Y ¿Cuánto hace que un filósofo serio y crítico no es a la vez maestro de vida? Quizás más de cien años.

$Y$ ahora imaginemos que estamos cerca de este hombre, cuya imagen de cabeza beethoveniana, bigote Bismarckiano y cabellera rubia alada es conocida por todos; oímos que una bella periodista le pregunta ${ }^{8}$ si es cierto que él se considera optimista, a lo que Sloterdikj, con parsimoniosa y con su cavernosa voz de bajo responde: Si hace veinte años me hubiera usted formulado esa pregunta, con toda seguridad asistiría usted al enrojecimiento de mi rostro, pues a todo intelectual le estaba prohibido el campo del optimismo, sin embargo, hoy existen motivos más que razonables para ser optimistas.... $\stackrel{9}{\text {. }}$

\section{2.- LOS DOS PUERTOS DESDE LOS QUE PARTE EL OPTIMISMO}

Dos son los puntos de partida del presunto optimismo de Sloterdijk en sus dos últimas grandes obras escritas hasta hoy, Zorn und Zeit (Ira y Tiempo) y Du muss dein Leben ändern (Has de cambiar tu vida), el primero consiste en el creciente reclamo, la recomprensión y la reinserción de los impulsos "timóticos" del ser humano -ira, orgullo, afirmación de sí mismo entre otros-. Y el segundo punto de partida es la comprensión del ser humano como un ser en ejercicio. Presuntamente en estas sus dos ultimas grandes obras, se dejan ver ambos indicios del optimismo. Aunque ya adelantamos que en absoluto es el optimismo el punto de partida formal del pensamiento de Sloterdijk en estas 
obras, y añadiremos que, de ser el optimismo el punto de llegada, lo es muy de rebote y gratuitamente. Esta es por adelantado nuestra crítica al presunto "optimismo" de Sloterdijk como optimismo vacío que muestra, además, fuertes e irresolubles contradicciones con otros aspectos que también constituyen la base de su pensamiento. Su optimismo apenas está desarrollado, muy pocas son las páginas en las que puede verse tal visión esperanzadora y feliz de la realidad. Y creemos ver en Sloterdijk eso que él mismo veía en su magistral e insólito tratamiento de Wittgenstein en "Has de cambiar tu vida", un doble juego entre lo que se dice, lo que se insinúa y lo que no se dice $e^{\underline{10}}$.

Vayamos al primer motivo del optimismo, la posibilidad de reinstaurar en el ser humano lo que será un concepto fundamental en Sloterdijk: las fuerzas timóticas. El número de estas fuerzas nos lo va ampliando Sloterdijk: el orgullo, el valor, el arrojo, el impulso de autoafirmación, la exigencia de justicia, el sentimiento de dignidad, la indignación y las energías guerreras y vengativas. Combate Sloterdijk con decisión visiones de mundo que se oponen a estos sentimientos timóticos, especialmente a las "beaterías" cristiana -en primer lugar-, su enaltecimiento de la modestia y humildad y su desvío de lo timótico al pecado sumo de la "soberbia", y a la beatería psicoanalítica -en segundo lugarcuya dogmática afirma que ni siquiera el hombre más vigoroso puede ser algo más que un ser conscientemente tolerante de esa su condición de enfermo de

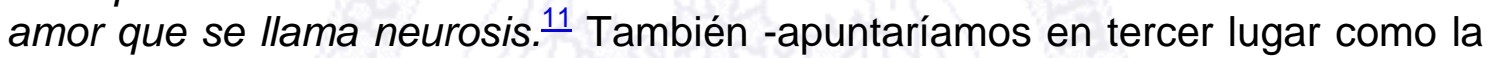
tercera beatería- el existencialismo francés -más tratado en Has de cambiar tu vida-, en el que ve un pesimismo incurable -recordemos el existencialismo trágico de Camus o la libertad como condena de Sartre $\stackrel{12}{-}$ que erradica del hombre las fuerzas timóticas.

Un nuevo impulso de lo timótico debe conducir más allá de las beaterías de la humildad, de las neurosis y del absurdo que conciben al hombre como un ser sin esencia, convertido en un parásito del ser, condenado a envidiar los cosas y a añorar su carácter sustancial $\underline{13}$.

La palabra griega que en el pecho de héroes y dioses designa el órgano del cual salen las grandes explosiones es "thymos" 14 , y más adelante afirma Sloterdijk entre guiones que quizás el término más adecuado para traducir el "thymos" sea el "arrojo" $\underline{15}$. Magistralmente comienza Sloterdijk comentando la que fue la "primera palabra europea", la "ira" -Canto I de la llíada- y de cómo esa ira, era una afirmación de uno mismo, una energía de la que uno estaba cargado sin ni siquiera necesitar de impulsos externos para concretar la ira. De esta forma exagera Sloterdijk y ensaya -casi en tono de broma- un substancialismo ontológico del impulso timótico de la ira cuando dice: Aquiles está lleno de ira de la misma manera que el Polo Norte es de hielo, el Olimpo está rodeado de nubes y el monte Ventoux se ve rodeado por el viento...Esto no excluye que las provocaciones de la ira preparen el escenario...pero su papel se limita a provocarlo sin modificar su esencia. Como fuerza que mantiene unido en su intimidad un mundo en litigio, la ira garantiza la unidad de la substancia en la pluralidad de las erupciones ${ }^{16}$. Esta ira manifestada por Homero forma una unidad entre el héroe que la porta el Dios que la defiende y el poeta que la canta. La ira es apelada en Homero a algo superior, pues aunque sea la quinaesencia, la substancia del sujeto, es evocada e invocada por el poeta y se encuentra en unión con la voluntad de los dioses. Lo que se manifiesta a través de la ira es una no-impotencia y una no-indiferencia $\underline{17}$. El 
análisis de lo heroico que nuestro pensador hace en las primeras páginas de Ira y tiempo enlaza plenamente con la exigencia "metanoética" que fluye por todos los lados de su obra posterior Has de cambiar tu vida. Estas inmersiones en la metanoia se hacen de forma individual y con un componente ético del que carece la heroicidad homérica, pero esta metanoia ética mantiene el fuego de la afirmación de uno mismo, del orgullo y de cierta ira. La diferencia entre la metanoia -antigua- y el thymos homérico reside en que este último formaba un componente total, Dios, héroe, cantor y espectador, mientras que el eremita del siglo $\mathrm{V}$ practicante de la metanoia antigua debía apartarse de la pudrición del mundo para afirmarse a sí mismo y mantener en vilo lo heroico del thymos. Platón mismo es señalado por Sloterdijk como un metanoético más, aquel que

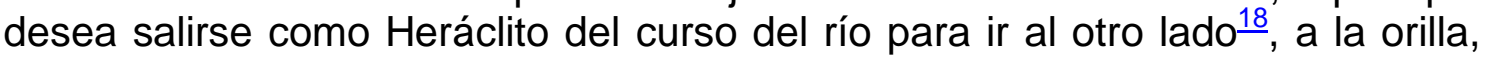
esta filosofía como atletismo es encomiada por Sloterdijk, sin embargo señala a Platón como el primer desviador de la heroica timótica homérica ${ }^{19}$. Es Platón quien desvía ese impulso timótico sustituyéndolo por un impulso erótico, entendiendo el amor como deseo de lo que no se tiene, como deseo de tener. Bellamente muchos manuales e historias de la filosofía griega comienzan con este eros platónico como una carencia, explicando el origen de la palabra filosofía como amor a la sabiduría que no se tiene $\underline{\underline{20}}$.

Lo que se ha opuesto en la historia a lo erótico no ha sido lo timótico, sino el control de la erótica mediante el dominio de las pasiones, desverticalizando con ello lo erótico mismo, ya se manifestara "mundana" o "divinamente" ante el peligro del excesivo amor o fusión divinas, -de controlar esto último ya se encargó la ortodoxia-.

Pero Sloterdijk ha visto mucho más allá y de forma más críticamente esta sustitución de lo timótico por lo erótico. Mientras que el erotismo manifiesta caminos hacia los objetos que nos faltan y a través de los cuales nos sentimos complementados, la timótica abre a los hombres caminos por lo que ellos son capaces de afirmar lo que tienen, pueden, son y quieren ser. Lo erótico ha triunfado en sus dos manifestaciones, una erótica a Dios o una erótica al cuerpo y a las cosas. El consumismo actual ha logrado la implantación a gran escala de esta erótica y sólo restituyendo esta erótica por el orgullo de ser sí mismo, de afirmarse a sí mismo, ve Sloterdijk motivos de cambio y esperanza en lo humano. ¿Hay que volver pues a Homero? ¿Es Aquiles ejemplo pues de actuación? No podemos confundirnos a este repecto, la respuesta de Sloterdijk es un tajante, "no", pues pese a la simpatía de Sloterdijk por los modos antiguos de existencia, pese a su inmensa crítica a la modernidad, es sobre

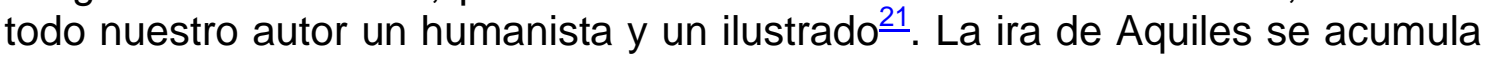
hoy de forma organizada y planificada en nuevos bancos de ira que mezclan la pura ira heroica homérica con la metanoia monoteísta, es el caso del fundamentalismo islámico y no puede Sloterdijk eludir este tema de vital importancia y actualidad $\stackrel{22}{2}$. ¿Es la ira del fundamentalista islámico un timos a ser restaurado? Evidentemente no, y lo veremos más detalladamente en últimas páginas de este ensayo. Sin embargo, Sloterdijk puede llegar a confundir a un lector no muy introducido en su filosofía, dado que nuestro pensador es uno de los pensadores camaleónicos más enormes que jamás hayan existido. Sí, Sloterdijk es capaz de sentir la ira de Aquiles y comprenderla -ponerse en su lugar- como la del fundamentalista islámico, como capaz es de comprender a san Francisco al proferirse él mismo las 
heridas que serán "estigmas" hechos directamente por Cristo. No hemos de olvidar esta capacidad camaleónico-creadora de nuestro escritor. Es por ello la existencia en su obra de fuertes efectos, efectos que al modo de la irrupción de un Diógenes han de entenderse como una sacudida necesaria. Los libros de Sloterdijk son sacudidas que a veces confunden al lector no acostumbrado y entrenado con sus obras. Estas sacudidas tienen lugar ya al comienzo de sus obras, la sacudida de la ira de Aquiles, imparable, bélica y destructora con la que comienza Ira y tiempo o la imagen de Rilke contemplando los restos de la estatua de Apolo, su torso y que nos apela desde todos sus ángulos a "cambiar nuestra vida", o la sacudida de contemplar a los equilibristas que andan por la cuerda tensa y que se arriesgan a caer, sacudidas con las que comienza Has de cambiar tu vida. Estos efectos de choque van siendo domesticados por el mismo escritor a lo largo de sus exposiciones, sin que dejen de perder su valor y sin que a lo largo de las obras dejen de presentarse para sacudirnos de nuevo. Por lo tanto, la respuesta a la pregunta de restituir un Aquiles dentro de nosotros es "no". Pero sólo teniendo como faro que la historia de la humanidad se ha decantado por lo erótico ante lo timótico, sólo teniendo eso en cuenta podremos restituir lo timótico, hacernos uno con el impulso en la utopía de una vida motivada $\underline{\underline{23}}$.

Pero lo timótico no reemplaza ni debe reemplazar a lo erótico. Esto ha de quedarnos claro. Lo timótico reestructura lo erótico, social y psicopolíticamente. En esta superación reside la anhelada sustitución de la tan repetida exigencia posmoderna de "amarse a uno mismo", -como un limpiado y restituido narcisismo- por la de "afirmarse a uno mismo", pues en la afirmación de sí mismo ve Sloterdijk un mejor campo adaptativo de la idea de ejercicio antiguo y un mayor trasfondo ético.

Dado que tratamos de ver los motivos optimistas y las propuestas psicopolíticas de Sloterdijk tenemos que preguntarnos por las soluciones para la restitución de lo timótico en nuestro mundo actual. Esencial en esta idea de la "autoafirmación de sí mismo" es que bajo ella percibe Sloterdijk un resquicio por el que el altruismo puede volver a respirar, pues ve que el ser que más logra la afirmación de sí mismo es el que da, el dador, el donante. El dador -der Geber-, el donante -der Spender-, es aquel que con más fuerza se afirma a sí mismo y en ese resquicio se depura la contaminada atmósfera psicopolítica que contempla al hombre como deudor y no como dador que es la idea impuesta en los Estados modernos. El desarrollo histórico es el cambio de la visión del hombre de dador a deudor, esto ya nos lo advirtió Nietzsche, y Sloterdijk traza la figura esencial del hombre contemporáneo -al menos en occidente- como un sujeto en deuda con su banco $\stackrel{24}{ }$, y a mayor escala en deuda con su Estado. La iglesia, en su ensalzamiento de la santidad comprendió en parte esta estructura timótica, haciendo que los más santos fueran los más capacitados para desprenderse, pero la neurosis del desprenderse no se potenciaba con nada que no fuera la mera exaltación de la humildad. El santo no podía hacer gala de su santidad, no podía afirmarse si no era negándose y humillándose, que son formas dudosas de afirmación de uno mismo. De ahí la interpretación lúcida de Sloterdijk del por qué de los estigmas en los santos, pues el santo tenía que hacer ver que él era el señalado, que él era el elegido, que llevaba signos de santidad, pues sólo así se afirmaba a sí mismo mucho más allá de lo que exigía la coartante y negadora humildad $\stackrel{25}{ }$. 
La idea del dador o donante nos sacude de manera especial -recordemos lo que hemos afirmado de sus sacudidas- cuando Sloterdijk presenta al "agresor como donante" en Ira y Tiempo. El que agrede no hace sino explotar de ira por una considerada injusticia; en su explosión da a quien él considera que lo merece lo que cree que le falta, sufrimiento ${ }^{\underline{26}}$. Este distanciamiento ilustrado para comprender la ira del otro es una sacudida no meramente literaria sino también filosófica, si bien no definitiva. Sloterdijk analiza todos los campos de la ira, desde la explosión inmediata del donante agresor hasta su canalización en el orgullo del pagador de impuestos. En efecto, no hemos dicho mal. Muy lejos de esta visión del agresor-donante tenemos el pagador de impuestos como donante; aquí aplica Sloterdijk su consideración de lo timótico a un esbozo de filosofía fiscal, bajo la cual el contribuyente debe ser entendido como un donante y no como un deudor. ${ }^{27}$ Claro que para dar es menester poseer, y he aquí donde emerge una defensa a ultranza de la propiedad privada. Tema ya desarrollado antes por Sloterdijk, sin ir más lejos en Esferas III al hablar del habitar como inmunología $\underline{28}$. El que la propiedad privada sea esencial para que el hombre se afirme a sí mismo como donante, ¿liberará al hombre de impulsos a poseer más, aunque sólo tenga ese tener el dar como fin? He aquí una de las grietas por las que Sloterdijk tiene que pasar en su aterrizaje a la política real.

$Y$ ahora veamos el segundo aspecto mediante el cual Sloterdijk ve un futuro con optimismo. $Y$ es el enseñar y considerar la vida como ejercicio, la vida es un ejercitarse. En esta vida en ejercicio encuentra Sloterdijk el campo en el que el timos se llena de sentido, en el esfuerzo personal ${ }^{29}$, la recuperación de lo que él denomina sentido de la verticalidad, se construye el puente por el que la ira, el orgullo y la afirmación de sí mismos pasan como por su naturaleza. Todo ser se ejercita. Es esa la "esencia" del ser humano, ejercicio y más ejercicio $\underline{30}$. Este ejercicio llega a ser ascesis, declarada o no declarada, y recuerda la visión de Nietzsche en la Genealogía de la moral, según la cual si desde un astro lejano se mirara la tierra no se vería a esta de otra forma sino como un astro ascético. Sloterdijk desarrolla la desespiritualización de la ascesis llevada a cabo por Nietzsche. Una desespiritualización ya acontecida en la modernidad donde al asceta lo sustituye el artista -que a su modo no estaba exento de espiritualización- y que en nuestros días parece sólo competer al deportista de élite. A la ascesis de cualquier tipo ha acompañado siempre un sentido de la vida en "vertical", sólo que en épocas antiguas en las que el hombre veía a su alrededor solamente corrupción y pecado, esa ascesis de unos pocos era de una verticalidad extrema. Así pues la vida en ejercicio, que en ciertas épocas fue vertical para unos pocos, ha visto con el devenir histórico, declinada su pendiente vertical para que mayor número de seres humanos puedan sentirse partícipes de empresas "grandes". En el sentido de lo "vertical" y "horizontal" se encuentra una de las numerosas claves -para nosotros una clave fundamentaldesde la cual interpretar Has de cambiar tu vida y por ende, comprender la vida humana en ejercicio.

\section{3.- LA EXISTENCIA VERTICAL}

Has de cambiar tu vida es, exceptuando la importantísima primera parte introductoria "El planeta de los seres ejercitantes", una historia de la 
antropotécnica, desde el mundo antiguo hasta el mundo actual, siendo esencial en esa antropotécnica la búsqueda y el desarrollo de sistemas inmunológicos simbólicos -como hemos apuntado, la religión es uno de ellos-.

Esta antropotécnica puede ser resumida como el proceso que lleva a los seres humanos desde una vida individual en ejercicio y en un esfuerzo que apunta hacia lo vertical hasta una vida en ejercicio comunitario y horizontal. Esta idea está ya recogida -crítica y catastróficamente- en innumerables pasajes de la historia de la filosofía, pero quizás haya sido Nietzsche quien mejor la ha expresado al diferenciar en Así habló Zaratustra la modernidad como la etapa en la que predomina al hombre-arbusto y a la antigüedad como la etapa en la que algunos hombres-árboles destacaban por encima de la sequedad del paisaje. En el sistema de producción moderno-capitalista es donde se produce la plantación y poda continua de los hombres-arbustos y el consiguiente ensalzamiento del trabajo asalariado como la vía "santa" para la producción de objetos comerciales $\stackrel{31}{ }$. Del eremita se pasa al trabajador asalariado. Los monasterios comunes en los que los eremitas solitarios se unieron siguieron siendo al fin y al cabo lugares de verticalidad individual. Es la nuestra una historia que lleva al ser humano desde la búsqueda de la perfección, del sacrificio, del martirio y del dolor hasta la producción, la competencia y la cualificación.

Sloterdijk sentencia de esta forma el pensamiento de la poda moderna del hombre: Si se debiera resumir en una única frase la diferencia esencial entre el mundo moderno y el antiguo y determinar con la misma frase esas dos situaciones del mundo habría que decir. Moderna es la época que ha llevado a cabo la más alta movilización de las fuerzas humanas bajo el signo del trabajo y la producción, mientras se llama antiguas a todas las formas de vida donde la suprema movilización se hacía en nombre del ejercicio y la perfección ${ }^{32}$.

La era del capitalismo salvaje, sin embargo, es la era horizontal, para la que es fundamental que los hombres se dejen hacer y no se hagan sino sólo mediante ese dejarse hacer: La tendencia a la desverticalización de la existencia da pasos de gigante: culto al cambio de lugar en el turismo, culto a la caducidad en el existencialismo, culto al derroche en el vitalismo. En esta época desespiritualizada parece que sólo a los deportistas de élite compete mantener vivo el fuego de lo exagerado ${ }^{33}$.

Es ahora cuando interviene una continua disputa entre Sloterdijk y el espíritu de la Escuela de Frankfurt -y también del existencialismo francés ${ }^{34}$-, para estos últimos la modernidad y su capitalismo salvaje trae una nueva Edad de hierro. El pesimismo, el absurdo son filosofías de fácil calado en el siglo XX -no sin razón- pero Sloterdijk, aún apreciando la clara consecuencia entre la desverticalización de la existencia y el capitalismo, pretende repensar y defender la modernidad como una Edad de plata, manteniendo la globalización, y un sentido "transcapital" del capitalismo -insistiremos más adelante en el apartado del transcapitalismo-. En Esferas III trata Sloterdijk de que la verticalidad le es inherente al hombre, aunque no tanto al modo de construcciones de escaleras de Jacob o de ascesis mortificante, sino que en esta obra Sloterdijk habla de verticalidad como "levitación", y esta entendida como "sostenimiento". El sostenimiento es la situación existencial primaria del ser humano -contra el arrojamiento heideggeriano. Vertical es entendido aquí por Sloterdijk como situación existencial de riqueza del ser humano, situación 
de lujo de los sapiens. El lujo del mimo de la madre hacia el hijo, y también de las instituciones civilizatorias -alomaternales- es desde el que se fundamenta en su origen toda la teoría de la riqueza y la propiedad privada en Sloterdijk ${ }^{35}$. Ya insistiremos más adelante el débito del optimismo rousseauniano ante esta visión de Sloterdijk.

Desde esa situación originaria que es fundamentalmente tratada en Esferas pueden las fuerzas timóticas, el orgullo, la ira, la afirmación de sí mismo -con el matiz de la recomprensión-extirpación del resentimiento- ser reinsertadas con éxito sólo en una sociedad de bienestar que trasplante a la actualidad la original situación de riqueza del ser humano.

El sendero a seguir propuesto por Sloterdijk en Has de cambiar tu vida es un caminar hacia delante que no sea completamente horizontal, sino con una inclinación vertical, que no llegue a las locuras de los antiguos. Ni las altas cumbres de los románticos, ni la Escala de Jacob bíblica, ni la irrupción de la verticalidad social -lo que Sloterdijk Ilama "metanoia política"- del comunismo, del nazismo o del fundamentalismo islámico, que pretenden imponer a todos de forma inmediata esa verticalidad $\frac{36}{}$. Sloterdijk utiliza -ya lo hemos sugerido más arriba- la imagen de las edades del hombre de Hesíodo, donde la Edad de plata es encomiada por encima de la edad de Hierro, de la edad de bronce y la inexistente edad de oro. La modernidad, depurada de sus equivocaciones y desvíos, debe verse como el triunfo de la edad de plata, y al filósofo no ya como un héroe del pensamiento sino como "un asesor que explica las ventajas de no vivir ya en la edad de hierro". Aquí sintoniza Sloterdijk con las filosofías de Richard Rorty y John Dewey para quienes la filosofía ha de ser depurada de su tendencia heroica, a la que ven dominada por un inherente romanticismo, fundado en la inspiración. Más allá de ello la filosofía no puede ignorar las luchas sociales, los intentos igualitarios legítimos y quizás deba la filosofía convertirse en una oficina de traducción trocando el saber heroico en un saber civil $^{37}$. Se ha de contradecir con un lenguaje medio a los conservadores grandilocuentes que siguen cultivando el idioma de la edad de hierro como si no hubiese pasado nada. En la misma tonalidad se habría de contestar a los ideólogos de izquierda radical, cada vez más virulentos, los cuales desilusionados por el fracaso del retorno a la edad de oro, hacen todo lo posible por denigrar a la edad de plata como una farsa ${ }^{38}$.

En este sentido hemos de entender la inserción de Sloterdijk en la modernidad, definiéndola como era postmetafísica, y entendiendo que la metafísica necesitaba de la miseria, ya fuera el hambre o la miseria de la costra de las costumbres y los malos hábitos, para existir desde la otra cara. Ya en Esferas III dedica un interesante capítulo contra los conservadores melancólicos de esta era miserabilista y heroica -entre los que no olvida incluir a Adorno, sorprendentemente- y contraponiendo ante ellos un término clave para el optimismo de Sloterdijk: el término "Verwöhnung", que no debe ser traducido únicamente por "mimo", sino por atención, cuidado, dedicación, confort, regalo, halago, obsequiosidad, bienestar, $\operatorname{comodidad}^{39}$. La modernidad es una era postmetafísica por ser posmiserabilista. Pero pese a ello, la inclinación vertical en una era posmiserabilista ha de ser nuevamente reivindicada, de otra manera. Por su designio igualitario, la modernidad se ve obligada a volver a formular todas las verdades, a las que ahora sólo tenía acceso una minoría -se refiere esencialmente el autor a las verdades del desprecio de lo mundano que sobre 
todo compete al héroe ético antiguo-, convirtiéndolas en verdades para la multitud.... con ello se priva de sus cimientos al extremismo de las prácticas ascéticas, pero dando la razón a sus tendencias $\underline{40}$.

La inclinación vertical es lo más costoso en la modernidad y lo que Sloterdijk reivindica de ella, dado que la verticalidad exige una constante diferenciación ética entre los modos de ejercitarse, y la modernidad ha presentado formas de vida en adaptaciones múltiples de duración corta, evitando así el verticalismo de ejercicio costoso y lento que requiere ser y convertirse en modelos. En el apartado dedicado a la educación y al arte actuales -posmodernos- se ven los enormes peligros de una modernidad que ensalza la repetición no para ejercitarse en referencia a modelos a seguir, sino que repite para cerrarse en sí misma, para justificar el mismo estatus. Así por ejemplo, el fin de la escuela es la escuela misma ${ }^{41}$, el terminarla, sin más, abriendo así la boca el monstruo cínico de la modernidad: sistemas de autoreferencia que quedan sacralizados en su autoreferencia. Evitar la imitación de modelos éticos y circunscribirse en autoreferencias de sistemas cerrados, ese es el peligro fundamental de un ejercicio maligno.

Por ello la modernidad no debe olvidar a los pioneros verticalistas. Nada sería más ajeno a los "pioneros de la diferenciación ética" que el espontaneismo moderno, que cultiva per se como valores estéticos el "shock, la irritación, la interrupción de lo acostumbrado sin preguntarse qué debe reemplazar a lo interrumpido $\underline{42}$.

Se han de examinar esas antiguas formas de aquellos ejercitantes espirituales por si son reutilizables para encontrar entre ellas formas nuevas. Podría empezar un ciclo distinto de secesiones, para sacar de nuevo al hombre, si no del mundo, sí de la apatía, del abatimiento, del atascamiento, y sobre todo de la banalidad, de la que Isaac Babel decía que era la contrarevolución ${ }^{43}$.

Es la voz oída por Rilke en el Louvre "Has de cambiar tu vida" con lo que Sloterdijk comienza la obra del mismo nombre, pero no nos cabe duda de que su leit motiv es Nietzsche. La interpretación sloterdijkiana del "superhombre" es insertada en el ámbito de lo artístico-acrobático. El artista acróbata que despierte las posibilidades del hombre, que para Sloterdijk son su acceso y vida en lo imposible. Normalizar lo imposible es la tarea del acróbata, posibilitar lo imposible. Para ello es menester partir de que el ser humano es un ser que aspira a lo imposible -he ahí un fundamento grande del optimismo que mantiene Sloterdijk-. El superhombre es aquel que sigue tensando la cuerda en alto y pasea por ella, aunque sepa que Dios ha muerto. La muerte de Dios no niega la existencia de las alturas, pero aminora el sentido de la verticalidad radical como una escalera -la escalera de Jacob- o como una huida vertical ante el apestado mundo. Quien se balancea en el alambre de las alturas vive de proporcionar a los espectadores un motivo para mirar hacia arriba ${ }^{44}$. Y con ese mismo leit motiv nietzscheano acaba su obra Has de cambiar tu vida, en el epílogo titulado "el imperativo absoluto". Todo individuo tendrá que admitir, si se analiza seriamente, que ha hecho de sí mismo menos de lo que según su capacidad, debiera haber hecho, exceptuando los pocos momentos en los que podría decir que ha prestado oídos al deber de ser un animal bueno. Como un animal mediocre, espoleado por ambiciones, infestado de símbolos excesivos, el hombre queda muy por detrás de lo que se pide de él, incluso cuando se enfunda el maillot de vencedor o los ropajes del cardenal$/ \underline{45}$. 


\section{4.-¿CAMBIAR EL MUNDO, CAMBIARSE A UNO MISMO, A NINGUNO O CAMBIAR LOS DOS A LA VEZ?}

Mientras que el hombre antiguo no tenía dudas respecto a esta pregunta y contestó siempre que el cambio había de ser personal -individual-, dirigiéndose a las más altas cotas de sacrificio y de ejercicio, que a veces conducían a una crueldad insólita respecto al practicante de dichos ejercicios, el hombre moderno, en cambio, es aquel que no sabe por dónde empezar, si por cambiarse antes a sí mismo, si por cambiar al mundo, los dos a la vez o ninguno de los dos. Quizás la excesiva oferta de nuestro mundo capitalista no sólo hace perder el tiempo pensando en el tipo de salsa a escoger de la estantería del supermercado, sino también hace perder el tiempo en este otro sentido. La oferta no sólo de productos, sino de ideas, de ideologías es tan inmensa, que el hombre pierde capacidad de actuación. Las ideas se han convertido también en productos expuestos en las estanterías del supermercado. Pero siguiendo con Sloterdijk, nuestro pensador es tajante en este punto, y su optimismo y modernidad no deben desviar el hecho de que Sloterdijk reivindica un giro hacia el mundo antiguo y hacia la idea de cambiarse a uno mismo. En este sentido retoma el estoicismo, múltiples son las citas de Séneca y Marco Aurelio en Haz de cambiar tu vida, siendo muy relevante su afirmación de que ni siquiera Marco Aurelio, como emperador, pensó en cambiar el mundo, sino en apartarse de él lo más posible y cambiarse a sí mismo. Ya hemos presentado a Sloterdijk como un pensador moderno, hemos mencionado su cercanía a las ideas de Rorty sobre el filósofo como civilizador, que antepone la democracia a la heroicidad y a la misma filosofía, hemos citado también su cercanía a esa frase de Goethe que nos advierte que los profetas bocean por la izquierda y por la derecha mientras en hombre camina por en medio de la vida. Pero no tenemos dudas de que quien lea atentamente a Sloterdijk y de forma muy especial Has de cambiar tu vida encontrará una mayor simpatía y sintonía del autor con las metanoias individuales antiguas, desestimando lo que él denomina "metanoia a mitad de precio", propia de la modernidad. La mayor cercanía de Sloterdijk con respecto a Séneca, Marco Aurelio y al autor medieval de la Imitatio Christi supuestamente Tomás de Kempis- que con respecto a los modernos es evidente. En Ira y tiempo no deja de aborrecer el camino intermedio, el centro, y en concreto el centro político al que califica como el más deforme de todos los monstruos, de constructor de híbridos de todo y con todo. $\underline{46}$ Así no olvida Sloterdijk que su irrupción en la escena filosófica en 1983 con Crítica de la razón cínica se produce tras pasar varios años en la India y admirar el cambio metanoético en el budismo y el hinduismo. En aquella primera obra habla Sloterdijk ya de ascesis individual y recela de lo que denomina un paralizador nosotros y una falsa universalidad ${ }^{47}$. Pese a ello Sloterdijk se gira sereno hacia la modernidad y la restituye sin vacilar en su pretensión universalizadora. Será el lector el que deba conciliar cómo ambos caminos, el cambiar la propia vida bajo inspiración de verdaderos maestros, propia de la metanioa antigua, puede unirse con la modernidad. Nosotros, no obstante tratamos aquí de dar claves a este respecto.

En qué dirección es menester cambiarse a uno mismo es algo que no se hace nítido en la obra de Sloterdijk hasta su final. Un lector que no conociera otras 
obras de Sloterdijk, al leer las primeras 100-200 páginas de Has de cambiar tu vida no sabría del todo si la recomprensión de la vida en ejercicio reivindica casi como iguales la vida en ejercicio del deportista de élite, del equilibrista, del filósofo y del empresario ${ }^{\underline{48}}$, y más de una vez nos preguntamos si puede un banquero, por ejemplo, cambiarse a sí mismo ejercitándose en su labor eficaz de banquero, sin más?

La vida en ejercicio compete a todo ser humano, los mismos conceptos de personalidad o libertad, en apariencia incuestionables, no son nada sin el ejercicio. Pero en esta vida humana en la que todo es repetición es menester "diferenciar éticamente". Llega Sloterdijk a definir al ser humano como el ser vivo condenado a "diferenciar" las repeticiones. $\underline{49}$ No hay duda en que el ejercicio y la repetición debe estar guiada por un contenido ético fundamental, que para Sloterdijk parte del humanismo cristiano y de la llustración, por más que estos queden disfrazados de "sistemas inmunológicos", pues, en todo caso, como nuestro pensador insiste en Si Europa despierta (1994), el humanismo cristiano y la llustración son los mejores de los sistemas inmunológicos pensados $\underline{50}$.

Por otro lado la reivindicación de lo mágico en lo cotidiano, el saberse rico sólo por existir en la cotidianeidad es otro aspecto importante para ejercitarse y

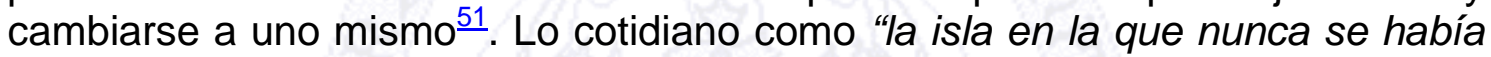
puesto el pie", como la tierra a ser descubierta, conduce al sentido de la vida cotidiana como vida en ejercicio. Cuando los antiguamente afiliados al existencialismo francés y a la filosofía del absurdo, así como cuando los estudiantes revolucionarios de 1968 cayeron en la cuenta de que nada es fecundo si se pretende primero cambiar al mundo, sólo entonces surge para Sloterdijk, por fin en el siglo XX la figura del "adulto". El adulto, a diferencia de la niñez del comunismo, del nazismo o del fundamentalismo islámico, entre otras formas de niñez, quienes adoptan la voluntad volcánica de cambiar el mundo imponiendo y arrastrando a los otros a dicho cambio, adoptando además una espiritualización en las formas de ascesis exigidas, en los sacrificios ejercitados y revitalizando el impulso timótico del resentimiento a gran escala para terminar en una ira más terrible que la ira de Dios $\underline{52}$, pues esta era desplazada al más allá, mientras que estos infantes apuntan a las destrucciones más terribles del más acá. Este enaltecimiento del adulto choca, sin embargo, fuertemente con el leitmotiv de la obra de Sloterdijk en la que el asombro "Das Staunen" es una y otra vez exigido como categoría fundamental del sujeto, restituyendo la figura del niño. ¿Cómo conciliar esto? He aquí la respuesta ensayada: El adulto no es sino el niño que mira desde el parque cómo los otros niños van detrás de la pelota ${ }^{53}$. Sólo él se admira tomando distancia, como el niño ante la pompa de jabón, contemplada y admirada desde la distancia. Es esta una teoría contemplativa, que sacude entre otras cosas a la industria del turismo, pensado para mover al hombre sólo en horizontal, cuando el mayor asombro está en mirar hacia arriba o hacia el horizonte desde la posición que se ocupa, lo cual es algo ya en sí vertical. Así, después de los sueños-observaciones, uno se da cuenta de que, al modo de los niños en Peter Pan, las cosas perdidas en el viaje de los sueños, aparecen en la habitación, que no se ha abandonado. Pero no hay dudas, el ejercicio compete a cada individuo. "Has de cambiar tu vida" y no "la vida", no "el mundo" es la voz que Rilke oye resonando desde la figura mutilada del Apolo del museo del Louvre. 
La frase se nos dirige a cada uno de nosotros como un imperativo, esta vez no salido de ningún Apolo, sino de la conciencia de que "así no se puede seguir", de que el mundo posmoderno ha atrapado al hombre en cárceles de costumbres, de las autoreferencias de los sistemas que se ahogan en su carácter autoreferencial, en la cárcel de la negación de su mismo impulso natural a lo improbable. Y es aprovechando lo positivo de la globalización como difusión del bienestar de cada individuo, como Sloterdijk construye su ontoclimatología, que reivindica la inserción -"reinserción"- de lo sublime, del sentimiento de lo sublime como algo personal. Lo sublime, cuya punta me señala a mí es personal como la muerte e inasible como el mundo ${ }^{54}$. La vida en ejercicio, en los buenos ejercicios resuena desde lo alto, desde la cuerda por la que anda el acróbata Nietzsche.

\section{5.- DE NUEVO EL MUNDO GLOBALIZADO. LA REINSERCIÓN DE LO TIMÓTICO EN EL SENO DEL MUNDO GLOBALIZADO. CAPITALISMO CONSUMADO O TRANSCAPITALISMO.}

La globalización ha mostrado, según Sloterdijk, que los procesos de cambio se insertan dentro de un funcionamiento lento. La globalización, pese a su rapidez expansiva, nos deja ver la existencia de otras culturas, de otras formas de vida, de otras épocas, y hace crecer en los más atentos la idea de que todo es evolutivo. En Si Europa despierta muestra Sloterdijk una Europa dormida desde 1945 hasta los años 90 del siglo pasado, sin embargo, veinte años más tarde, en Has de cambiar tu vida, valora la vida europea a partir de 1945 como un lento dejarse hacer mediante una praxis progresiva, más racional y europea, que apuntaba a la extinción de los radicalismos en Europa ${ }^{55}$. En este sentido, todo es transformable de forma lenta y evolutiva ${ }^{56}$. Es sólo dentro del mundo globalizado donde lo timótico puede ser fecundo. ¿Cómo el gran crítico de la modernidad, de la sociedad burguesa, que es Sloterdijk llega a tal conclusión? ¿En qué sentido es fecundo aquel "palacio de cristal" descrito en Esferas que es el mundo occidental capitalista, y que es mirado desde fuera por los pertenecientes al tercer mundo, a los cuales se les permite a veces entrar en el palacio?

En Esferas III ya nos ha preparado Sloterdijk el camino para una valoración positiva del capitalismo. La fecundidad de éste consiste en que nos ha sacado de una época miserabilista, en la que la metafísica, la antropología, la filosofía en general, partían de la condición de "carencia", esencial al ser humano. Sloterdijk se aleja de esta metafísica de la carencia y apuesta por una situación diferente como esencial al hombre, el "lujo"del existir humano ${ }^{\underline{57}}$. El hombre es un ser de lujo por su apertura al mundo, por la capacidad de elección. El capitalismo ha puesto de cara esa esencia del hombre como ser de lujo, contra el ser de la carencia. El ser humano se ha sacudido recientemente muchas de las cargas características de la era miserabilista, y aunque siempre habrán nostálgicos -la mayoría de los intelectuales- que pregonan una vuelta al miserabilismo, a la carencia, a la carga, Sloterdijk se fija en el lujo del aligeramiento de las cargas, lo que en ocasiones llama "levitación". Especialmente contra Hegel, Gehlen y en este caso también contra Heidegger, quienes quieren volver, cada cual a su modo, a una situación de carencia y 
sólo ven en la situación de lujo del ser humano un peligro, sitúa Sloterdijk la positividad de lo logrado por el capitalismo. Cuando el hombre se sienta como ser sobreabundante, en excedencia, como ser mimado, como ser levitativo, "argonauta del espíritu" -citando a Nietzsche-, es cuando los impulsos timóticos del dar, de la sobreexcedencia, harán que el capitalismo siembre en su seno la autoafirmación timótica. Claro, que podríamos preguntarnos qué sucedería si la levitación a la que hace referencia Sloterdijk no sea sino el modo contemporáneo de la carga, de la gravedad; es decir, si el aligeramiento de la carga tuviera el sentido de implantarnos más cargas, nuevas cargas, ya anunciadas por doquier en la historia de la filosofía de los tres últimos siglos. Y si la levitación no fuera sino el suave y plácido ascenso en globo que nos saca de la atmósfera respirable y nos hace reventar.

En este sentido nos parece Sloterdijk extravagante, para él por ejemplo, hay conatos de cambio, del capitalismo al transcapitalismo en el concepto de "imagen", "Bild" en el sentido de que el tránsito de imágenes, absoluto y horizontal y que llega a todos en un mundo globalizado de imágenes, de intercambio, puede hacer surgir la idea del mundo como un sistema de redes que refieren trayectos individuales o grupales y no tanto homogeneización. En este "trayecto individual" se descubre la vida individual en ejercicio, se revitaliza el hacer por encima del dejarse hacer, propio del peor momento del capitalismo globalizado.

Pero también el capitalismo más atroz ha usado la imagen para homogeneizar, estandarizar. Y aquí es donde al aterrizar topa el pensamiento de Sloterdijk con el primer peligro de estrellarse, pues no sólo da por supuesto la libertad y eticidad en el intercambio y en el fluir de las imágenes, sino que más allá de la eticidad, el autor pone el acento en el intercambio de imágenes en el intercambio de imágenes artísticas. Un sueño novaliano y rilkeano, un fundamento ético que ya no se basa tanto en la inmunología y en el interés o en el orgulloso timós, sino en la imagen pictórica, escultórica, arquitectónica, y especialmente en la música ${ }^{58}$.

De forma más clara Ira y tiempo y Has de cambiar tu vida pretenden "aterrizar", y por ello, de forma más clara aún topan con rocas agrietadas por donde el autor pretende pasar en su aterrizaje. He aquí donde encontramos su defensa a ultranza de la propiedad privada como vía de salvación del mundo, que ya hemos traído más arriba. Toda mejora del mundo pasa por una extensión lo más generalizada posible de la propiedad privada ${ }^{59}$. Los países pobres habrán de promover la extensión de la propiedad privada. Deja hablar a Locke y a su tríada "vida, libertad y propiedad privada". El tener, el ser propietario devolverá al hombre un impulso timótico esencial, el de su orgullo, y el de la afirmación de sí mismo, pues sólo el que tiene da, y sólo el que da se afirma a sí mismo. Esta posesión no sólo es referida a bienes espirituales, sino también a bienes materiales. Esto puede ser una verdad incontestable, pero Sloterdijk quiere socavar más en esa verdad y desarrolla un esbozo de filosofía fiscal -ya lo hemos indicado más arriba- en el que entiende al contribuyente como un donante o un dador y al Estado receptor le compete la tarea de agradecer y hacer saber al contribuyente que el Estado le queda agradecido por sus "donaciones", tal como hace Suiza -de hecho Sloterdjk habla en este sentido de la necesaria helvetización de Europa y del mundo- $\frac{60}{}$. Este aspecto del capitalismo como un revitalizador del impulso timótico en el hombre en tanto 
que "dador" o "donante", sienta sus bases en el apartado "Capitalismo consumado, una economía de la generosidad" el sentido del bien común, y el concepto de "comunidad", distinto al concepto de "sociedad"62. Aquí Sloterdijk hace aparecer al capitalismo como el desplazador-conversor ideológico de la culpa-deuda moral en deuda monetaria. El tiempo de la culpa está marcado por la persecución del delincuente por las consecuencias de sus actos....liquidar y pagar por una culpa son actos que sitúan la prioridad del retorno en el punto medio de las transacciones. Son las operaciones objetivas cuya traducción acontece en la sensación subjetiva del resentimiento ${ }^{63}$. Y ahora es cuando Sloterdijk apuesta y vislumbra un "transcapitalismo" dentro del capitalismo. Este transcapitalismo debe ser visto en orden a su "ontoclimatología" que ve al ser humano como un ser llamado a armonizarse con los otros ${ }^{64}$. Esta ontoclimatología está inserta en una cadena de donaciones originarias, que convierten a la riqueza y al dar en algo constitutivo del ser humano. Una cadena del dar que va desde la madre al hijo, del padre a la madre -en la estructura antigua familiar-, de la naturaleza y la sociedad hacia la madre y al padre. Otro sueño sloterdijkiano, un principio armónico de dávidas, no distinto al de Dios-Padre-Espíritu- Iglesia-fieles. De esta armonía davidosa constituyente surge su teoría fiscal, que se funda en una economía que integre no sólo la gratificación del ser sostenido ante el sostenedor ${ }^{65}$, sino también el perdón al infractor, pues Sloterdijk cree que poniendo bien en juego los impulsos timóticos del orgullo, el gesto de perdonar incrementará en el deudor el impulso timótico de devolver, de dar ${ }^{66}$. Claro que el fisco no se pagará a ninguna esfera, sino a una estructura concreta, llamada federación, país, nación, pueblo. Pero esa estructura concreta no podrá desarrollarse sin el transcapitalismo, sin una globalización que impulse la timótica fundamental del ser humano como donante o dador. Esta fuerza timótica conduce a una economía timótica alternativa en relación con la inversión económica -y también con la teoría fiscal, en la que la riqueza está presente en relación con el orgullo.

Pretende arrancarle al bienestar moderno la máscara fúnebre tras la que se esconde el desprecio que a sí mismos se profesan los propietarios mezquinos de grandes y grandísimos patrimonios, un desprecio que en el sentido de la doctrina platónica del timos, es totalmente legítimo, ya que el alma de los acaudalados se ataca a sí misma con razón cuando no encuentra la salida del círculo de la insaciabilidad. Contra ella ni siquiera sirve la afectación cultural corriente en el medio: el interés por el arte, que en general es la cara dominguera de la codicia. La cura contra el desprecio por uno mismo la encontraría el alma de los acaudalados únicamente en las buenas acciones que vuelven a ganar los aplausos internos de la parte noble del alma ${ }^{67}$.

Esta tendencia transcapitalista y timótica de la economía y la gestión de las riquezas es llamada por Sloterdijk -ya lo hemos traído antes- tendencia "antigravitatoria", ya que entiende el gran peso gravitatorio histórico los conceptos de deuda y culpa, que Nietzsche supo analizar tan certeramente. Nos parece ver en este transcapitalismo antigravitatorio aquella imagen que tan bellamente es trazada en Esferas, cuando el niño se asombra de la pompa de jabón salida de su boca y fluye serena hasta su disolución, bajo la mirada del niño, que admira lo creado por él, su fluir, su magia, su transparencia, y sabe sin embargo que en poco tiempo se deshará. La antigravitación como aumento 
de la improbabilidad $\underline{68}$ es lo que nuestro pensador desarrollará en Has de cambiar tu vida como vida del ejercitante trapecista, que desafía a la gravedad, y hace de lo imposible lo posible, es decir aumenta lo imposible. Sin embargo, en Esferas III queda claro que este dar antigravitatorio entra en primer plano porque Sloterdijk lo entiende como algo constitutivo del ser humano. Por supuesto, Sloterdijk evitará hablar de esencias o condiciones humanas -no lo hará de forma clara y notoria hasta la última página de Esferas III al hablar de la sexualidad como "impulso hacia arriba"- $\underline{\text { sin }}$ embargo, entiende con Nietzsche que el ser humano es en su "constitución", un ser de lujo, de apertura radical al mundo. El ser humano ha cometido una continua minusvaloración de sí mismo debido a la influencia del supercontrol ejercido por la filosofía de la carencia y todos los defensores del "homo pauper"; así huye de su esencia de lujo, de su orgullosa constitución como ser que da. Es aquí donde el volteriano Sloterdijk, pasa casi a ser rousseauniano $\underline{70}$. La bondad natural de Rousseau se mezcla con la nobleza y fortaleza nietzscheana y surge el más que interpelante"ser davidoso" de Sloterdijk, al que pese que le tildemos de "volteriano", "rousseauniano"...nos habla con una fuerza y una magia insólitas. Pero nos compete analizar su obra, sigamos pues con ello.

Sloterdjk ha percibido que este transcapitalismo provendría de lo que el mismo Marx comprendió: una era del transcapital sólo acontecería cuando el capitalismo haya llegado a su consumación total. Pero se deja ver en Sloterdijk una filosofía de "espera", en el que los grandes sistemas económicos desaparecen por sí mismos, mientras el hombre deberá entretanto velar y ejercitarse para el cambio poscapitalista. Los sistemas de Lenin y Mao son vistos por Sloterdijk como la irrupción de la impaciencia que no deja que el capitalismo se ahogue por sí mismo, presentándose desde fundamentalismos políticos y oportunismos bélicos, a partir de los cuales se perdía el sentido del éxito de la economía, de la evolución y la sucesión ${ }^{71}$. Y sobre todo la precipitación del comunismo radica en la erradicación de algo sagrado para el hombre -y desde luego para nuestro pensador-: la propiedad privada y lo propio.

Sin restaurar el orgullo en el hombre y el gozo de dar, no puede irrumpir este transcapitalismo. Es el mismo empresario quien quizás tenga la primera palabra. La economía timótica -del orgullo- es atisbada ya por el empresario Andrew Carnegie, a quien Sloterdijk cita: "quien muere rico llena su vida de infamia". La revisión de lo timótico no sólo incide en una teoría fiscal que pone su énfasis en el dar, sino que Sloterdijk desarrolla algo que ya había expuesto George Bataille, un nuevo rumbo en el concepto de inversión.

Bataille vislumbra en los escritos de Nietzsche los contornos de una economía del orgullo, mediante la cual el concepto de inversión se ve modificado radicalmente. Mientras los inversores comunes usan sus recursos para recuperar más de lo que han empleado (su tiempo es eo ipso tiempo de espera, del return on investment), los otros emplean sus recursos para satisfacer su orgullo y atestiguar su suerte, que privan a los dadores de la espera de beneficios en la misma moneda, mientras las ganancias de reputación y entusiasmo son legítimas y deseables (el tiempo de este segundo inversor es el tiempo de la transmisión de una riqueza que genera importancia)...los inversores de este segundo tipo entienden que el valor en cuanto tal sólo se forma cuando se crea a través del gasto de sí mismo y de los propios recursos a favor de la existencia de cosas que están por encima de todo precio... los 
ricos de este segundo tipo hacen cosas con su patrimonio que nunca podría realizar un animal que sólo aspira a tener más y más $\underline{72}$.

Pero por más cierto que puedan ser los análisis y las propuestas de Sloterdijk, nos parecen discutibles, pues en el fondo no se trata sino de sembrar en este mundo lo que hasta ahora se ha entendido que pertenecía a otro mundo, y que Sloterdijk "enfría" o decora contemporáneamente, bajo su concepción de inmunología general. Se nos ocurre aquí la similitud del fondo sloterdijkiano con una carta de Tolstoi dirigida al zar Alejandro III, en la que el novelista ruso, ya convertido casi en profeta religioso, suplica al recién proclamado Zar Alejandro el perdón para los terroristas que acabaron con la vida de su padre Alejandro $1{ }^{73}$. La carta de Tolstoi no tuvo respuesta por parte del zar -"pese a ser este cristiano"- y nos tememos que las soluciones de Sloterdijk queden igualmente sin respuesta, "pese a sabernos parte de un sistema inmunológico general". El dador, es el que es también capaz de perdonar. En alemán dador es "Geber" y el que perdona es "Vergeber", nótese como en alemán está más caracterizado el perdonar como un dar supremo, es decir como un acto timótico de orgullo y afirmación de uno mismo. Pero nos tememos que tal como Alejandro III, nosotros seguimos considerando el modo de vida como un archivo en el que se anotan las faltas, tal como el Dios juez y archivero ${ }^{74}$. Pero la caja de resonancia de esto que comentamos se percibirá mejor si traemos aunque sólo sea en extractos aquella misma carta de Tolstoi:

....Usted seguramente alberga en su alma un sentimiento de venganza hacia esas personas por ser los asesinos de su padre...y además creerá que no es sólo un sentimiento de venganza personal, sino que es su obligación y lo que espera de usted toda Rusia. Ahí está la tentación es en la que radica el horror de la situación en la que usted se halla...parece que no hay sino dos caminos, o las enégicas medidas represivas o la indulgencia liberal...pero hay otro remedio del que nada saben los médicos, ¿por qué no probarlo? Este remedio tiene una ventaja intrínseca sobre los demás remedios y es que esos ya han sido utilizados sin resultado alguno y este todavía no se ha utilizado nunca ¿Por qué no probar, en nombre de Dios, cumplir su ley sin pensar en el Estado ni en el bienestar del pueblo? En el nombre de Dios y en el cumplimiento de su ley no puede haber ningún mal. El nuevo remedio no sólo resulta natural al alma humana, sino que le procura una alegría suprema y una gran felicidad. Perdonar y pagar el mal con el bien es el bien en sí mismo. Así, sé que el bien y el amor se derramarán por toda Rusia ${ }^{75}$. No podemos dejar de sorprendernos de las semejanzas de la filosofía inmunológica de Sloterdijk con esta carta de Tolstoi, quizás su fuente común sea el perdonar no siete, sino hasta setenta veces siete, o el amad a vuestro enemigos y orad por los que os persiguen.

Pero Sloterdijk no cesa en su empeño de insertar su altruísmo civilizatorio en un sistema racional-materialista, ya que no hay nada que nuestro pensador deteste más que los imperativos categóricos formales, de corte kantiano. Bajo nuestro punto de vista, sin embargo, su pretensión de hacer no sólo racional sino egoístamente racional su altruismo, sirve en Sloterdijk para enmascarar su discurso metanoético individual, más ético y ecológico que material racionalista, más kantiano de lo que el mismo Sloterdijk cree.

Pero insistirá el pensador de Karlruhe en que su filosofía es racional-egoísta, de contenidos, y no sólo formal. Es desde esta idea desde la que Sloterdijk insiste en fundamentar su compromiso mundial mediante la base de la teoría 
inmunológica, una "inmulogía general" o un "co-inmunismo". El hecho antes analizado de la globalización hace ver por primera vez que el hombre no existe solo, ni existe como una nación, ni grupalmente, la esfera de lo propio y lo ajeno es modificada radicalmente. Pues lo ajeno es reubicado desde la perspectiva de la globalización cada vez más como lo propio, reinsertando así, de paso, todas las filosofías que Sloterdijk ha traído como base de su pensamiento, entre ellas Heidegger y su ser-en-el-mundo. Partiendo de la existencia de una "sociedad planetaria" conjunta, teje un sistema de mantenimiento conjunto, al que llama "sistema inmunológico ampliado". Se amplía el concepto de inmunidad individual en vistas a una inmunidad grupal, y de la inmunidad grupal a la planetaria. Analiza la historia como una historia por las luchas de sistemas inmunitarios más o menos cerrados, que acababan en los beneficios de sistemas inmunológicos que lograban abrirse -pero en su autoreferencia- más que los otros, en los cuales quedaban sin participación los perdedores (ya sean de naciones, de sectas religiosas...). Hoy, como siempre, siguen los sistemas inmunitarios eludiendo una sociedad planetaria: la actual situación del mundo se caracteriza por no poseer ninguna estructura inmunitaria conjunta que sea eficiente para los miembros de esta "sociedad planetaria". En el plano más alto la solidaridad sigue siendo una palabra vacía. Se le puede aplicar, ahora como antes lo que dijo un conocido estadista: "Quien dice humanidad trata de engañar". La razón es evidente: las unidades efectivas de solidaridad coinmunitarias serían hoy día, como lo eran en tiempos pasados, de tipo familiar, tribal, nacional e imperial, y desde hace poco, también formateadas en alianzas regionales estratégicas; funcionan, en el caso de que funcionen, de acuerdo con los formatos respectivos de diferenciación entre lo propio y lo ajeno $\frac{76}{\text {. }}$.

Pensamos que la base de la teoría sloterdijkinana no la forma algo tan frío egoísmo, inmunidad- como el autor pretende hacer ver en muchas ocasiones, pues no vemos en esta frialdad más que el velo que intenta ocultar lo que pasa "arriba", en lo alto, ya que Sloterdijk funda el sentido de su inmunología en la cuerda tensada en lo alto por Nietzsche. Sloterdijk nos habla de que la globalización trae de nuevo la figura del adulto como protector de sí mismo protegiendo al mundo, sin embargo, no deja de reivindicar la falta de profetas, de acróbatas que muevan dicha inmunología, cuyas psiques son en buena medida contrarias a las de los adultos. La coinmunidad -insiste Sloterdijkdifumina el concepto de lo propio y ajeno, y quedarían colapsadas las distinciones clásicas entre el amigo y el enemigo. Pero no podemos dejar de preguntarnos cómo se inserta la propiedad privada dentro de la inexistencia de lo propio y ajeno, o de lo ajeno como propio y lo propio como ajeno. Los rompecabezas para intentar endosar el concepto fundamental de propiedad privada de Sloterdijk, que ya hemos tratado más arriba, en su "inmulogoutupía" son más que irresolubles.

\section{RESUMIENDO Y LEYENDO ENTRE LÍNEAS}

En la teoría fiscal esbozada por Sloterdijk, es decir en su aterrizaje político tenemos de nuevo la suposición de que el Estado ha sido limpiado de toda corrupción, y tenemos, nada menos, la mucho mayor suposición de que al 
pagar el contribuyente, lo hace por cosas que le benefician, como si la construcción de tal edificio o redes de ferrocarril fueran sin ninguna discusión beneficiosas en sí mismas.

Su teoría de la propiedad privada, es decir a más propiedad privada más solución social, ¿tapará u ocultará a caso el impulso a tener más propiedad privada que el otro? ¿Acaso el que todo el mundo tenga propiedad privada hace superar lo que para Sloterdjk es la fuerza timótica dañina, la seta venenosa, que es el resentimiento -que él lee brillantemente en la acumulación de bancos de ira, pero obvia en los aspectos más pequeños y comunes, como un motor esencial de la vida? Y como el autor ha analizado portentosamente en Esferas III, la propiedad privada, ¿no vendrá a fortalecer el sentimiento de autoreferencia, de vigilancia continua y de "explosión de la autoatención", síntomas nefastos de esclavismo actual ?구

Y para mayor asombro, nuestro autor hace aquí -ya lo hemos dicho- que Locke y Nietzsche se den la mano, pues la ya citada tríada Lockeana de "vida, libertad y propiedad privada" entra en armoniosa simbiosis con la liberación del espíritu del resentimiento de Nietzsche ${ }^{78}$. Aquí debemos leer entre líneas al escritor de Karlruhe. Ya hemos apuntado, tanto en las primeras páginas de este ensayo, como unas líneas más arriba que el resentimiento es un impulso timótico, que conduce a la venganza. Bien, nos permitimos leer entre líneas a Sloterdijk, tal como él hace con Wittgenstein o Foucault. $Y$ es que creemos que para Sloterdijk el resentimiento debe mantenerse como impulso fundamental de la vida. De hecho expone que no hay crítica sin resentimiento ${ }^{\frac{79}{}}$, y a donde vamos, pretendiendo enlazar Ira y tiempo con Has de cambiar tu vida, es precisamente en este punto. Quizás sea una máxima histórica el hecho de que no puede cambiarse el mundo sin cierto resentimiento, pero lo que entre líneas está en Sloterdijk es que uno no puede cambiarse a uno mismo sin cierto resentimiento, sin una "tamización", "atenuación" del resentimiento, también podríamos llegar a decir utilizando y conjuntando conceptos sloterdijkianos, sin una "europeización" del resentimiento. La crítica ha llegado en occidente a su desarrollo y Sloterdijk agradece esto sorprendentemente al verticalista Pablo y al sistema verticalista impositivo del comunismo -tan criticados, sin embargo por el mismo autor-. Tanto uno como otro mantuvieron viva la llama de la inaceptabilidad del mundo de la injusticia. Pero el retorno de la Europa humanista e ilustrada, y así parece haberlo hecho la globalización capitalista como metanoia a bajo coste, no quema el resentimiento por completo, sino que lo recicla para el cambio de uno mismo.

"Mira tu naturaleza rica, tu ser lujoso y falto de carencias ya desde el origen y más ahora en la sociedad del bienestar y no te dejes encantar por filosofías de la carencia y del pauperismo (Esferas III). Tu ser lujoso tendrá que restablecerse con tus fuerzas timóticas, con tu orgullo, con tu "resentimiento europeizado" -nos permitimos añadir-, (Ira y tiempo). Así habrás de cambiar tu vida, huyendo de verticalismos inhumanos, pero no perdiendo de vista que ser humano no es nunca un estar arrojado, sino un ser que camina siempre hacia arriba, que se eleva (Has de cambiar tu vida)".

Así podríamos nosotros resumir y enlazar estas tres grandes obras de Sloterdijk. El optimismo de esta teoría que criticamos, ya lo hemos apuntado: El roussonianismo matizado de la situación de lujo original del ser humano, la ética universal cristiano-ilustrada que hará gestionar esas riquezas propias del 
ser humano, siempre en un marco de libertad-poder personal (idealismo); una ética que debe estar aliada con el progreso, pues este es siempre un impulso hacia arriba. Quede así resumido este ensayo.

\section{NOTAS}

1 Personajes asignados por lo general a bajos profundos. Don Basilio, personaje de "El Barbero de Sevilla" de Rossini, asignado por lo general a un bajo buffo profundo y cuya aria principal es "La calumnia". Felipe II, personaje de Don Carlos de Verdi y Sarastro, personaje de "la flauta mágica de Mozart". Los tres los traigo aquí con cierta intención de describir mediante ellos a Peter Sloterdijk. En este ensayo se verá por qué he elegido precisamente estos dos personajes, Don Basilio y su calumnia, Felipe II y su rigor y Sarastro y su anhelo de amor universal, caracterizan a Sloterdijk.

2Cf. Hans-Jürgen Heinrichs: Sloterdikj: Die Kunst des Philosophierens. Hanser Verlag, München, 2011. p. 64.

3Hans-Jürgen Heinrichs: o.c, p. 60.

4 Cf. Sloterdijk: Du muss dein Leben ändern; Suhrkamp Verlag, Frankfurt am Main, 2009, p.672 y 707-709. Sloterdijk: Has de cambiar tu vida, Pre-textos, Valencia 2012, p.541 y 570-71. pero todo su pensamiento sobre "Inmunología" (religiones, instituciones o viviendas) está extensamente desarrollado en Esferas, especielmente en Esferas III. Insistiremos en este concepto de "inmunología" más adelante.

5Citado en: Sloterdijk: Du muss dein Leben ändern; edición, citada; p.693 o en la traducción española: Sloterdijk: Has de cambiar tu vida, edición, citada, p. 557.

6 No olvidemos que dos de sus fuentes más inspiradoras son Rilke y Novalis.

7Prólogo de Rudiger Safranski a la obra: Sloterdijk: Esferas I; Siruela, Madrid, 2011, p.13.

8Véase la entrevista a Sloterdijk que Katja Gentinetta realiza magistralmente, en el programa de la SF suiza "Sternstunde".

9La traducción es mía.

10Cf. Sloterdijk: Du muss dein Leben ändern; edición citada; p.210-230, pero especialmente el apartado titulado "Was sich zeigt", p.225-228. En la traducción española: Sloterdijk: Has de cambiar tu vida; edición citada, p.177-194, pero especialmente el apartado "lo que se muestra" (p.188-190).

11Sloterdijk: o.c, p.30. Sloterdijk: Zorn und Zeit; Suhrkamp, Frankfurt am Main, 2008, p. 35-36 Sloterdijk: Ira y tiempo, Siruela. Madrid, 2010, p.30.

12Una excepcional interpretación de Sartre como falso maestro la encontramos en: Du muss dein Leben ändern, edición citada, p.679, en la traducción española: Has de cambiar tu vida; edición citada, p.545.

13Cf. Sloterdijk: Si Europa despierta; Pre-textos; Valencia, 2004, p.23.

14Sloterdijk: Zorn und Zeit; edición citada; p.24. En la traducción española: Sloterdijk: Ira y tiempo, edición citada, p.22.

15Sloterdijk: o.c, p.25, en la traducción española, p.23.

16Sloterdijk: Zorn und Zeit; edición citada, p. 17. en traducción española: Ira y tiempo; edición citada, p.17.

17Sloterdijk: o.c., p. 11. En traducción española: o.c, p.13.

18Sloterdijk: Du muss dein leben ändern; edición citada, p.304-307. En traducción castellana: Sloterdijk: Has de cambiar tu vida, edición citada: p.252-253.

19Por supuesto que tendrá Sloterdijk, una vez más aquí a Nietzsche como referencia.

$\underline{20}$ El ejemplo más bello que ahora se me viene a la mente respecto a este tópico, no por ello incierto, es la obra de Jean Francois Lyotard: ¿Por qué filosofar?

21Y más adelante veremos como la "beatería" que él imputa al cristianismo y al psicoanálisis, acaba convirtiéndose en base de su mismo pensamiento por más disfrazado que se presente desde una teoría "inmunológica" que lleve a una solidaridad "egoista". Lo veremos más adelante.

22Aunque su primer gran tratamiento de la ira como verdadera empresa, como verdadero banco de gestión está dirigido a su visión del comunismo. (Cf. Sloterdijk: Zorn und Zeit. Edición citada; 171-284)

23Así cita Sloterdijk a Robert Musil en: Sloterdijk: Zorn und Zeit, edición citada, p.21. En traducción española: Sloterdijk: Ira y tiempo, edición citada, p. 20. 
24Cf. Sloterdijk: Du muss dein leben ändern; edición citada, p. 580-581. En traducción española: Sloterdijk: Has de cambiar tu vida, edición citada, p.468-469

25Cf. Sloterdijk: Du muss dein Leben ändern; edición citada; p.485-486. En la traducción española: Sloterdijk: Has de cambiar tu vida, edición citada, p.395-396

26cf. Sloterdijk: Zorn und Zeit, edición citada, p.89-91. En traducción española: Ira y tiempo, edición citada, p-71-72.

27Esta polémica teoría fiscal enlaza con el optimismo humanista, ilustrado y capitalista que criticaremos más adelante en Sloterdijk.

28Cf. Sloterdijk: Esferas III; Siruela, 2006; p.407-415.

29Él mismo habla al final de Zorn und Zeit de que lo que se pretende es una meritocracia, que desde el punto de vista intracultural como transcultural equilibre una distendida moral antiautoritaria con una conciencia marcada de las normas y con un respeto a los inalienables derechos personales (Cf. Sloterdijk: Ira y tiempo, edición citada, p.274)

30La primera definición de "ejercicio" en Has de cambiar tu vida es esta: Defino como ejercicio cualquier operación mediante la cual se obtiene o se mejora la cualificación del que actúa para la siguiente ejecución de la misma operación, independientemente de que se declara o no se declara a ésta como un ejercicio (Cf. Sloterdijk: Has de cambiar tu vida; edición citada, p.17) 31Lutero abrió este camino antropotécnico horizontal al concebir que el acceso a Dios puede hacerse desde cualquier punto de la tierra -y no sólo en los monasterios e iglesias- y desde cualquier posición social, no sólo al sacerdote que se arrodilla o eleva el cáliz sino al tendero y al herrero en sus oficios.

32Cf. Sloterdikj: Has de cambiar tu vida, edición citada, p.271. En el original alemán: Sloterdijk: Du muss dein Leben ändern, edición citada, p. 329.

33Sloterdijk: Has de cambiar tu vida ,edición citada,p. 513. En el original alemán: Sloterdijk: Du muss dein leben ändern; edición citada, p.638.

34Aunque hay que decir que los frankfurtianos apenas son citados por Sloterdijk.

35Cf. Sloterdijk: Esferas III; p.574-575, pero especialmente todo el apartado "Primera levitación. Para la naturaleza del impulso hacia arriba" (p.565-579).

36Una vez más salta a la vista la ambigüedad de Sloterdijk, pues este camino "intermedio" de inclinación o desnivel no exagerados es criticado en Si Europa despierta, al hablar de que el motivo de la distensión -que él apunta como uno de los peligros del hombre contemporáneoconsiste en instituir una débil diferencia en el seno de un desnivel insignificante (Cf. Sloterdijk: Si Europa despierta; Pretextos, Valencia, 2004, p.30.)

37Cf. Sloterdijk: Du muss dein leben ändern, edición citada, p. 669. En traducción española, Sloterdijk: Has de cambiar tu vida, edición citada p.538.

38Sloterdijk: Has de cambiar tu vida, edición citada. p.539. En el original alemán: o.c; 670.

39Sloterdijk: Esferas III; Siruela, p.511 y ss.

40Sloterdijk: Has de cambiar tu vida, edición citada p.537. En el original alemán: o.c; p.668.

41Cf.Sloterdijk: Du muss dein Leben ändern; edición citada, p.684. En traducción española: Sloterdijk: o.c; p.546-550.

42Sloterdijk: Has de cambiar tu vida, edición citada, p.516-517. En el original alemán: o.c; p.641.

43SSloterdijk: Has de cambiar tu vida, edición citada, p.561. En el original alemán: o.c; p.698.

44 Sloterdijk: Has de cambiar tu vida, edición citada, p.154. En el original alemán: o.c; p.182

45Sloterdijk: Has de cambiar tu vida, edición citada, p.564. En el original alemán: o.c; p.701.

46 cf. Sloterdijk: Ira y tiempo; edición española citada; p.221, edición alemana: p.284.

47Cf. Heinrichs: o.c; p.62. La traducción es mía.

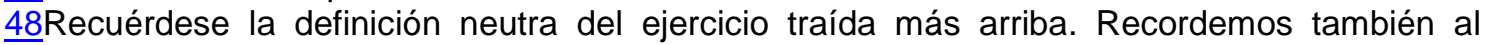
respecto de lo que aquí comentamos su cita de Foucault en la que este afirma que nunca en su vida había encontrado a un "intelectual" sino únicamente a gente que escribe novelas, gente que trabaja con enfermos, gente que enseña, gente que pinta, o gente "de la que yo jamás he entendido muy bien si alguna vez hacen algo, pero intelectuales jamás (Cf. Sloterdijk: Has de cambiar tu vida, edición citada; p. 197).

49Sloterdijk: Has de cambiar tu vida, edición citada p.515. En el original alemán: o.c; p.639.

$\underline{50}$ No dejar de leer- los apartados dedicados a las tres "repeticiones malignas" que tienen lugar en el siglo XX: la educación metanoético-política de los totalitarismos, especialmente del comunismo, sobre todo por su capacidad duradera, de tres generaciones de campos de concentración. Esta primera repetición maligna es necesario completarla con los tratamientos del autor sobre el comunismo en la misma obra: p. 471-514 de la traducción española. , la 
debilitación del factor educativo en la pedagogía contemporánea y el ilusorio rechazo de la imitación en la estética moderna; p.542-554 de la misma traducción española.

51Sloterdijk sabe muy bien que esta condición existencial difícilmente es aplicable al llamado tercer mundo.

52Cf, Sloterdijk: Zorn und Zeit; edición citada; p.45-49. En traducción española: Sloterdijk: Ira y tiempo, edición citada; p.38-40.

53Cf, la citada entrevista a Peter Sloterdijk en: "Sternstunde", en la SF suiza.

54Sloterdijk: Has de cambiar tu vida; edición citada, p.564. En el original alemán: o.c; p.701.

55Cf. Sloterdijk: o.c., edición española citada, p.512.

56Esta característica fundamental de la lentitud de los procesos históricos es la que adopta el mismo "Dios" tras el diluvio, quien después de descargar su ira, deja de ser fundamentalista para ser realista. En este ejemplo cita Sloterdijk la gran obra de Safranski El mal y el problema de la libertad" (Cf: Sloterdijk: Ira y tiempo, edición citada p.96.

57Cf. Sloterdijk: Esferas III. 3 parte "Impulso hacia arriba y mimo" p.511 y ss

58 Hans-Jürgen Heinrichs: Peter Sloterdijk, die Kunst des Philosophierens, edición citada, p.195 59Sloterdijk: Has de cambiar tu vida, edición citada; p.490. En el original alemán: o.c; p. 607. A cuenta de una crítica del comunismo ha escrito Sloterdijk en Ira y tiempo, que cuando este pretende la construcción de un escenario en el que sólo haya primeras filas de patio de butacas (Cf. Ira y tiempo, edición citada p.137). Podía haber aplicado el autor esta certera crítica a su concepto de la propiedad, aquí tan ilusoriamente traído.

60A Sloterdijk se le olvida comentar el agradecimiento que Suiza también debe a los delincuentes que ocultan su dinero en los bancos suizos. Sin duda Suiza también agradecerá a ellos sus "donaciones". Y tanto Suiza como el suizo se sentirán orgullosos de ser recaudador y recaudado, dado que siempre habrá dinero en exceso en sus bancos para todo lo que sea menester en la buena vida suiza.

61Cf. Sloterdijk: Ira y tiempo, p. 41-49. En el original alemán: o.c; p.50-61

62En la citada entrevista en la SF Sloterdijk reivindica el término de "comunidad" (Gemeinschaft) contra el de "sociedad" (Gesellschaft)

63Sloterdijk: Ira y tiempo, edición citada, p.42. En el original alemán: o.c; p.52.

64 Una forma de totalidad ética -y de totalitarismo- que no pasado inadvertida a Vázquez Rocca, quien incluye a Sloterdijk, pese a su "afrancesamiento", en la tradición alemana hegeliana, "totalitaria".

65Cf. Sloterdijk: Esferas III, p.579.

66Cf. Sloterdijk: o.c; p.43. En el original alemán: p.54.

67Sloterdijk: Ira y tiempo; edición citada,p.48. En el original alemán: o.c; p.59.

68 Sloterdijk: o.c, p.43, y Sloterdijk: Has de cambiar tu vida; o.c; p. 91.

69Cf. Sloterdijk: Esferas III, edición citada, p.645

70 Su deuda respecto a Rousseau se pone en claro al modificar las ideas de Bloch en "EI principio esperanza". Para Bloch hay una búsqueda, un sueño desde el principio que podrá o no plenificarse al final. Sloterdijk contrapone a ello: Si por el contrario la plenitud se coloca al comienzo se pasa a un modo de pensar en el que la carencia sólo puede introducirse epigenéticamente; aparece entonces, como el resto de lo malo, como privativum, como un efecto de expolio, como una disminución...Quien se ha bañado en el río del origen está cubierto por la imposibilidad de ser pobre, como Sigfrido por la sangre reseca del dragón (Esferas III; de.citada, p.585).

71Sloterdijk: Ira y tiempo, edic.citada, p.45

72Sloterdijk: Ira y tiempo, p.44-45.

$\underline{73}$ Este hecho histórico es conocido y comentado por el propio Sloterdijk en Ira y tiempo con el fin de demostrar otro orden de cosas bien distintas a las que aquí comentamos. Cf. Sloterdijk: Ira y tiempo; p.86.

74Cf. a este respecto de Dios como archivero, Sloterdijk: Ira y tiempo; p.97. En edición alemana; o.c; p.123.

75Tolstoi: Correspondencia; Acantilado, Barcelona 2008; p.416-427. Como se aprecia aquí he seleccionado sólo unos fragmentos de esta extensa, inmensa y sorprendente carta de Tolstoi al zar. Merece la pena leerla íntegra.

76Sloterdijk: Has de cambiar tu vida; edición citada; p. 572. en el original alemán: o.c; p.711.

77Cf. Sloterdijk: Esferas III; edición citada, p.630 y ss.

78Cf. Sloterdijk: Ira y tiempo p.273. En el original alemán: o.c; p.354.

$\underline{79}$ Cf. Sloterdijk: o.c; p.273. En el original alemán: o.c; p.354. 